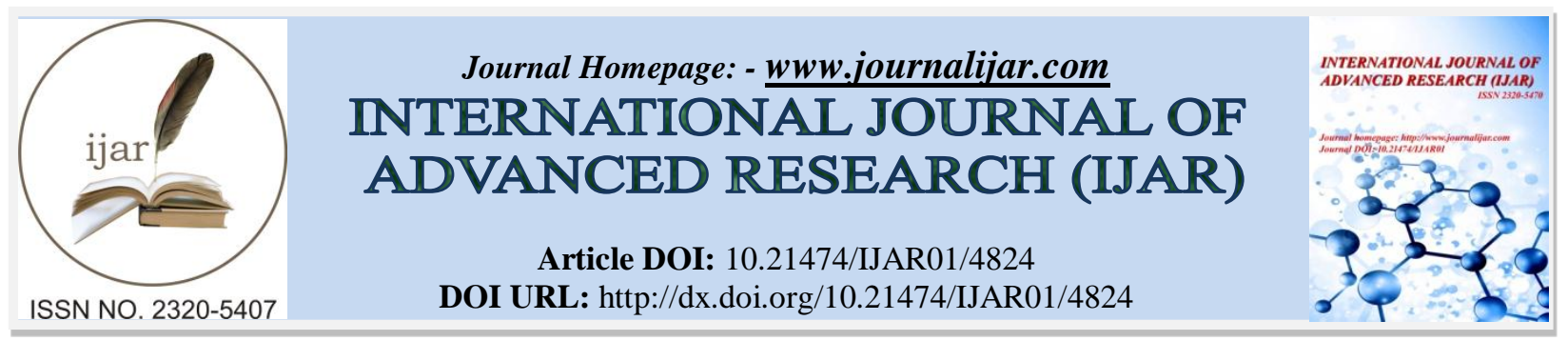

RESEARCH ARTICLE

\title{
DEVELOPPEMENT AND VALIDATION OF A QUECHERS EXTRACTION BASED GAZ CHROMATOGRAPHY-TANDEM MASS SPECTROMETRY “GC-MS/MS“ METHOD FOR THE DETERMINATION OF 7 POLYCHLORINATED BIPHENYLS RESIDUES IN BIVALVES "OYTERS".
}

\section{${ }^{*}$ Fatima Habti ${ }^{1}$, Soumia Belouafa ${ }^{1}$, Ahmed Bennamara ${ }^{1}$, Mustapha Tarhy ${ }^{2}$, Noureddine Fatini ${ }^{2}$, Abdelmjid Bahloul And Abdelmjid Abourriche'.}

1. Laboratory of Biomolecules and Organic Synthesis. Department of Chemistry. Faculty of Sciences Ben M'Sik. University Hassan II of Casablanca. Avenue Driss El Harti B.P 7955, Sidi Othmane Casablanca, Morocco.

2. Moroccan Laboratory of Agriculture (LABOMAG) . Department of Pesticide Residus.Km 10.500 Route de Zenata, Rue "J" n 1 Ain Sebaa, Casablanca, Morocco.

\section{Manuscript Info}

Manuscript History

Received: 12 May 2017

Final Accepted: 14 June 2017

Published: July 2017

Key words:-

PCBs, Bivalves, GC-MS/MS,

Validation, developement, QuECHERS

\section{Abstract}

Polychlorinated biphenyls have been determined in bivalve molluscs collected from OUALIDIA region in Morocco. It is a popular seaside resort of Moroccans, it is located $70 \mathrm{~km}$ south of El Jadida in the direction of Safi. Her Celebrity is due to its lagoon and oyster parks in September 2016.

High-performance analytical techniques are required for the identification and quantification of these persistent organic pollutants. The objective of this study is to develop a multi-residual analysis method for polychlorinated biphenyls in bivalves by gas chromatography coupled with quadrupole triple mass spectrometry. A global protocol comprising a QuECHERS version of the extraction step followed by a step of purifying the extract obtained on a mixture of the adsorbents was carried out. The developed method allows the quantification of 7 polychlorinated biphenyls in "Oyster" bivalves. Linearity $(\mathrm{R} \geq 0.995)$, specificity and selectivity, having an average efficiency greater than $70 \%$, repeatability, reproducibility, accuracy, are checked. As a result, the potential of the developed method has been demonstrated.

Copy Right, IJAR, 2017,. All rights reserved.

\section{Introduction:-}

Polychlorinated biphenyls, more commonly known as PCBs, are the synthetic organic substances, considered as priority chemical pollutants in both the United States and Europe, based on the lists established by the United States Environmental Protection Agency (EPA) and the Commission of the European Communities (Official Gazette of 14 $\mathrm{n} / 82)[1,2]$. They are synthetic chemicals and their commercial production began in 1929. These products are nonflammable, inert to acids, bases and other corrosive chemicals and require a temperature above $1000^{\circ} \mathrm{C}$ to allow their degradation complete.

Environmental contamination, both terrestrial and marine, cases of human poisoning and of animals caused by ingestion of foods accidentally contaminated with PCBs have motivated, over the last 30 years, the study of behavior and toxic effects of these compounds in the environment $[2,4,8]$.

Corresponding Author:- Fatima Habti.

Address:- Laboratory of Biomolecules and Organic Synthesis. Department of Chemistry. Faculty of 
PCBs that are widely distributed in the environment are classified as persistent organic pollutants (POPs), such as dioxins and polycyclic aromatic hydrocarbons (PAHs). There are two types of PCBs according to their mechanism of action: PCBs known as "Dioxin-Like" or PCB-DL. Their mechanism of action on cells is similar to that of dioxins: it binds to the same cell receptor and their toxicity is expressed as toxic equivalent factor in relation to the toxicity of TCDD (2,3,7,8- Tetrachloro-Dibenzo para-Dioxin) more commonly known as Seveso dioxin while PCBs called "Non Dioxin-Like" or PCB-NDL. They are found in larger quantities in river fish than Dioxin-Like PCBs. Of all PCBs, seven molecules are particularly found in contaminated products. They constitute indicator PCBs whose dosage is used to quantify the contamination of the products.[3,6,9]

Depending on the nature of the studied material, PCB analysis is carried out according to a more or less complex protocol comprising several steps: extraction of residues, purification of the extract, possible separation into groups of compounds, instrumental analysis by coupled gas chromatography triple quadrupole mass spectrometry and ultimately chemical confnmation. $[4,5,10]$

A variety of GC and HPLC methods have been developed for multi-residue determination of organochlorine pesticides employing a variety of sample preparation and cleanup techniques. In recent years, due to its rapidness, easy to use, effectiveness, reliability and safety, the QuEChERS method, as a new extraction method, has become a new sample pretreatment technology that is extensively adopted at home and abroad and is also widely applied in the gas or liquid chromatographic analysis for various pesticides.[1] [7][9]

In this work, the QuEChERS-GC-MS-MS method is used and validated to quickly determine the polychlorinated biphenyls residues: 2,4,4'-trichlorobiphenyl, 2,4',(-tetrachlorobiphenyl, 2,2',4,5,5'-Pentachlorobiphenyl, 2,3',3,4,4',5-Pentachlorobiphenyl, 2,2',3,4,4',5'-Hexachlorobiphenyl, 2,2',4,4',5,5'-Hexachlorobiphenyl, 2,2',3,4,4',5,5'-Hexachlorobiphenyl) in Moroccan bivalves "OYTERS".

\section{Materials and Methods:- \\ Equipment:-}

GC-MS/MS system Agilent Triple Quadrupole Mass Spectrometry 7890Awith Sensor Technologies 7000 MSD were used. Analysis is performed in MRM "Multiple reaction monitoring". The instrument is equipped with injector type Multi mode and an automatic sample changer 7693. The software type is mass hunter allows the acquisition to data processing and reporting. A refrigerated centrifuge SIGMA 4 bucketsand an Ultra-Turrax homogenizer were used for in extraction and purification steps.

The $50 \mathrm{ml}$ tubes are used for the deposition of the extract, $2 \mathrm{ml}$ tubes of centrifuge EFF and an analytical balance for weighing the samples.

Analysis by GC-MS/MS:-

The analysis of the molecules is done by MRM "Multiple reaction monitoring". A database of molecules provided by Agilent is composed by:

$>$ Retention time

$>$ Ions Relatives (Precursor ions) $(\mathrm{m} / \mathrm{z})$

$>$ Ions Son (product ions) $(\mathrm{m} / \mathrm{z})$

The conditions for chromatographic analyzes are detailed in Table 1:

Table 1:- GC-MS/MS conditions

\begin{tabular}{|l|l|}
\hline Colonne & $\begin{array}{l}\text { Agilent } 19091 \mathrm{~S}-433 \mathrm{HP}-5 \mathrm{MS} 350^{\circ} \mathrm{C}: 30 \mathrm{~m} * 250 \mu \mathrm{m} \text { In: front MM inlet He } \\
\text { Out: aux EPC } 4\end{array}$ \\
\hline Equilibration time & $0.5 \mathrm{~min}$ \\
\hline Max temperature & $350^{\circ} \mathrm{C}$ \\
\hline Oven programme & $70^{\circ} \mathrm{C}$ for $2 \mathrm{~min}$ \\
& Then $25^{\circ} \mathrm{C} / \mathrm{min}$ to $150^{\circ} \mathrm{C}$ for $0 \mathrm{~min}$ \\
& Then $3^{\circ} \mathrm{C} / \mathrm{min}$ to $200^{\circ} \mathrm{C}$ for $0 \mathrm{~min}$ \\
& Then $8^{\circ} \mathrm{C} / \mathrm{min}$ to $280^{\circ} \mathrm{C}$ for $1 \mathrm{~min}$ \\
\hline Run time & $32.867 \mathrm{~min}$ \\
& $5 \min$ post (run time) \\
\hline
\end{tabular}




\begin{tabular}{|l|l|}
\hline He quench gaz & $2.25 \mathrm{ml} / \mathrm{min}$ \\
$\mathrm{N}_{2}$ collision gaz & $1.5 \mathrm{ml} / \mathrm{min}$ \\
\hline Mode & MRM solvent vent \\
\hline Heater & $70^{\circ} \mathrm{C}$ \\
\hline Pressure & $33.274 \mathrm{psi}$ \\
\hline Temperature programme & $70^{\circ} \mathrm{C}$ for $0.07 \mathrm{~min}$ \\
& Then $600^{\circ} \mathrm{C} / \mathrm{min}$ to $325^{\circ} \mathrm{C}$ for $5 \mathrm{~min}$ \\
\hline Run time & $32.867 \mathrm{~min}$ \\
\hline
\end{tabular}

\section{Chemicals:-}

Acetonitrile is used as solvent for PCBs residues analysis. Also, the mixture of salts "anhydrous sulphate crystallized magnesium, hydrogen citrate, disodium citrate sesquihydrate and dihydratetrisodium" are used to saturate the aqueous phase and thus to achieve separation with the organic phase. This product is calcined at about $5500^{\circ} \mathrm{C}$ in an oven to remove all traces of phthalates, eg. FlukaNo. 63136. Adsorbents bulk of PSA (Primary and Secondary Amine) and adsorbent Suplclean LC-18, which are used for cleanup, have been selected for their physicochemical properties. The Preparation of standard solutions is based on the purity of standard organochlorine pesticides (Table 2).

Table 2:- The purity of PCBs

\begin{tabular}{|l|l|}
\hline Organochlorine pesticides & Purity \% \\
\hline PCB28 (2,4,4'-trichlorobiphenyl) & 99 \\
\hline PCB52 (2,4',(-tetrachlorobiphenyl) & 99 \\
\hline PCB101 (2,2',4,5,5'-Pentachlorobiphenyl) & 99 \\
\hline PCB 118 (2,3',3,4,4',5-Pentachlorobiphenyl) & 99.5 \\
\hline PCB138 (2,2',3,4,4',5'-Hexachlorobiphenyl) & 98.5 \\
\hline PCB 153 (2,2',4,4',5,5'-Hexachlorobiphenyl) & 99 \\
\hline PCB180 (2,2',3,4,4',5,5'-Hexachlorobiphenyl) & 99.5 \\
\hline
\end{tabular}

\section{Preparation of standard solutions:-}

The stock solutions of compounds were prepared individually from compounds of high purity, at $1 \mathrm{mg} / \mathrm{mL}$ in acetone. From these solutions, a standard multi-substance mixture was prepared in $10 \mathrm{ppm}$ of each compound in acetone. This mixture was used to determine the characteristics of ions of Q1 and Q3 SIM modes and transitions MRM mode.

In order to correctly assess the quantification limits and establish relevant calibration ranges, the mixture solutions were prepared in acetone depending on the compounds response coefficient. A wide range of concentrations was used. The previously prepared standard solutions are added to extracts of blank samples to compensate for the effect of matrix samples. The amount of extracts of blank samples used is equivalent to the extract of the sample concentration ready for analysis. These analytical standard solutions also contain quantities of internal standard equivalent to that contained in the extract of the sample ready for injection.

\section{Sample preparation Method:-}

Sample of oysters harvested from Walidia (Morocco) region, was placed in containers containing seawater and stored at $-20^{\circ} \mathrm{C}$ until use. After crushing, ground fibers were stored in a refrigerator $\left(-20^{\circ} \mathrm{C}\right)$.

\section{Extraction Method:-}

The procedure for sample preparation is described in Figure 1.Weigh $10 \mathrm{~g} \mp 0.03 \mathrm{~g}$ of the ground and homogenized sample, then put it into a centrifuge tube "FEP" $50 \mathrm{ml}$. Add, with a micropipette in all samples except the "blank samples fortified and White reactive", an amount of internal standard "or surrogate trace the sulfotep". Then, add a volume of $10 \mathrm{ml}$ of the acetonitrile extraction solution, on the Farm tubes and shake vigorously for one minute.

Next, add the mixture of previously prepared buffer salts ( $4 \mathrm{~g}$ of anhydrous magnesium sulfate, $1 \mathrm{~g}$ of $\mathrm{NaCl}, 0.5 \mathrm{~g}$ of Disodium hydrogen citrate sesquihytdrate and $1 \mathrm{~g}$ of trisodium citrate dehydrate) to the prepared suspension, on Farm tubes, shake vigorously for one minute without delay and ensure that the solvent reacts well with the entire 
sample and that agglomerates formed crystals were sufficiently dispersed.Then, centrifuge tubes at 3000rpm for 2 minutes.

\section{Cleanup}

An aliquot of the upper organic phase is transferred to a tube containing "150 mg of MgSO4, 50mg PSA and 100mg LC18" per ml of extract. After a mixing and centrifuging step, the purified extract is analyzed by GC-MSMS.

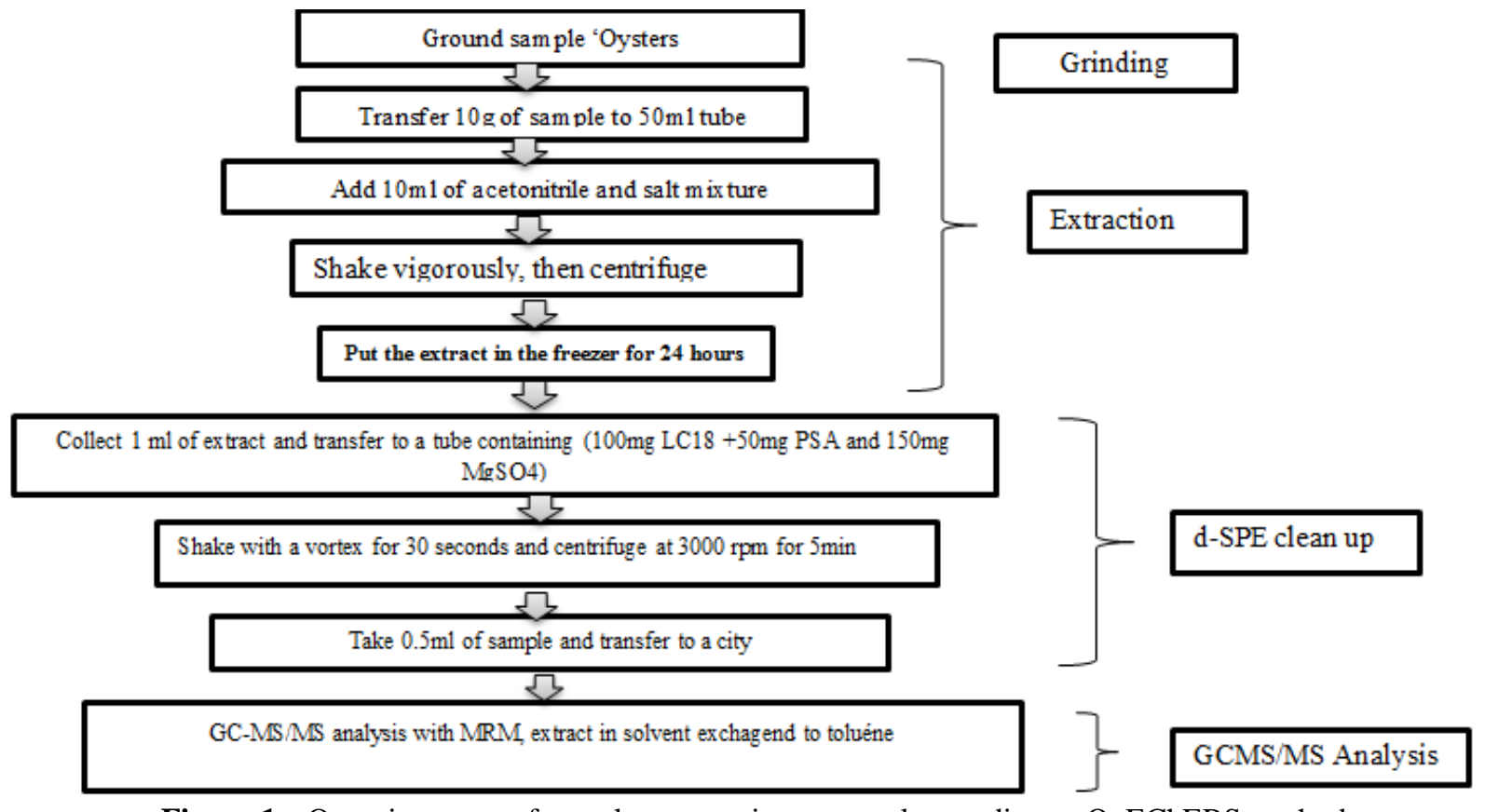

Figure 1:- Organigramme of sample preparation protocol according to QuEChERS method

Chromatographic Analysis:-

The injection of 0.2ppm mixed standard (7 PCBs) gave results presented in Figure 2 and Table 3.

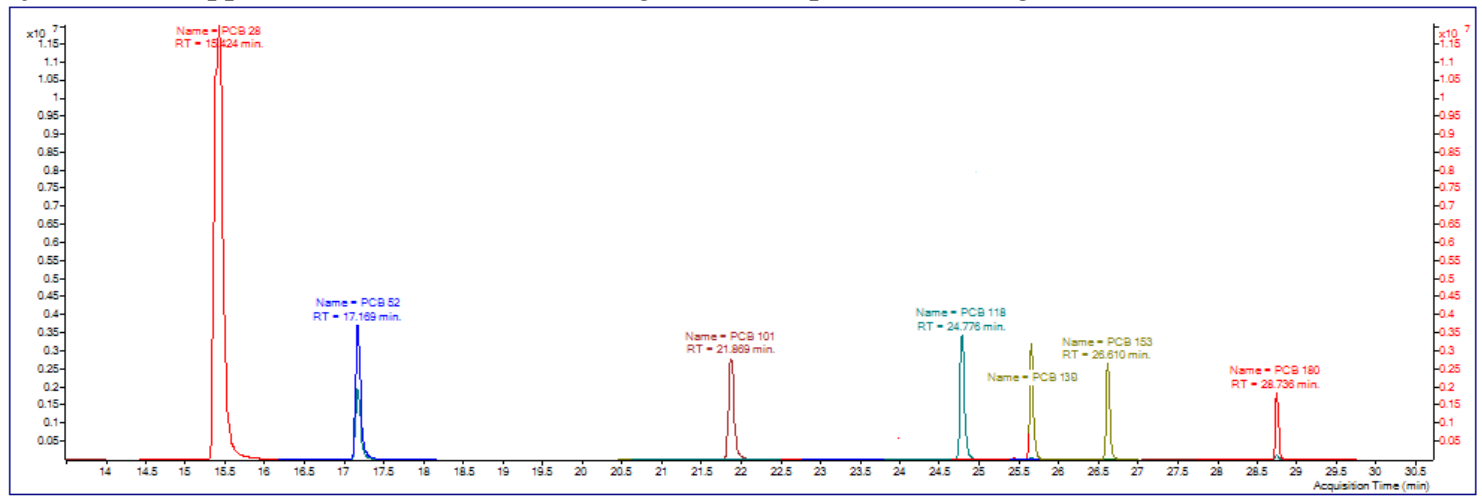

Figure 2:- Chromatogram of standard solution of 7 PCBs (0.2 ppm)

Table 3:- Retention times of standard solution of 7 polychlorinated biphenyls

\begin{tabular}{|l|l|}
\hline OrganochlorinePesticides & Retention Time (min) \\
\hline PCB28 (2,4,4'-trichlorobiphenyl) & 15.24 \\
\hline PCB52 (2,4',(-tetrachlorobiphenyl) & 17.16 \\
\hline PCB101 (2,2',4,5,5'-Pentachlorobiphenyl) & 21.86 \\
\hline PCB 118 (2,3',3,4,4',5-Pentachlorobiphenyl) & 24.77 \\
\hline PCB138 (2,2',3,4,4',5'-Hexachlorobiphenyl) & 25.68 \\
\hline PCB 153 (2,2',4,4',5,5'-Hexachlorobiphenyl) & 26.61 \\
\hline PCB180 (2,2',3,4,4',5,5'-Hexachlorobiphenyl) & 28.73 \\
\hline
\end{tabular}




\section{Method Validation:-}

Validation study of developed method, in this work, was studied according to NF T90-210 and the guidelines of Analytical Quality Control and Method Validation Procedures for Pesticide Residue Analysis in Food and Feed SANTE/11945/2015.

This validation was performed by the accuracy, precision, linearity and limit of quantification (LOQ).

Accuracy and precision data were obtained with recovery studies by spiking samples with polychlorinated biphenyls standards at levels of $0.2 \mathrm{ppm}, 0.1 \mathrm{ppm}, 0.05 \mathrm{ppm}, 0.02 \mathrm{ppm}, 0.01 \mathrm{ppm}$. The spiked samples were analyzed in 5 replicates. Precision of the method was evaluated through the relative standard deviations (\%RSD) associated with PCBs measurements during recovery.

Linearity was determined by plotting calibration curve with standard solutions in acetonitrile containing five different concentrations $(0.01,0.02,0.05,0.1$ and $0.2 \mathrm{ppm})$. Five injections were made at each of the five concentration levels.

The limit of quantification (LOQ) was determined according standard guidelines of Analytical Quality Control and Method Validation Procedures for Pesticide Residue Analysis in Food and Feed SANTE/11945/2015. Five independent analysis of oyster samples are prepared at a pre-assumed LQ value of $0.01 \mathrm{ppm}$ and then analyzed under intermediate fidelity conditions (VIM 2.24) «AFNOR 2010 NF V 03-110».

\section{Statistical Analysis:-}

The data were statically analyzed by using one way ANOVA. All statistical calculations have been done using Excel.

\section{Results:-}

Table 4:- Regression Equations and Criteria of Linearity.

\begin{tabular}{|c|c|c|c|c|c|}
\hline \multirow[t]{2}{*}{ PCB } & \multicolumn{3}{|c|}{$\mathrm{y}=\mathrm{a}_{0}+\mathrm{a}_{1} \mathrm{x}+\mathrm{a}_{2} \mathrm{x}^{2}$} & \multirow{2}{*}{$\begin{array}{c}\text { Coefficient of } \\
\text { Determination (r) }\end{array}$} & \multirow{2}{*}{$\begin{array}{c}\text { Correlation } \\
\text { coefficient }\left(\mathrm{r}^{2}\right)\end{array}$} \\
\hline & $\mathrm{a}_{0}$ & $a_{1}$ & $\mathrm{a}_{2}$ & & \\
\hline PCB28 & -8.81 & 6323.3 & 4277 & 0.9999 & 0.99996 \\
\hline PCB52 & -3.04 & 1081.3 & 607.3 & 0.9996 & 0.9998 \\
\hline PCB101 & -1.52 & 878.54 & 643.1 & 0.9998 & 0.9999 \\
\hline PCB118 & -2.91 & 1197.05 & 510.6 & 0.9997 & 0.9999 \\
\hline PCB138 & -0.48 & 707.43 & 648.8 & 0.9999 & 1.0000 \\
\hline PCB153 & -1.51 & 643.44 & 147.3 & 0.9999 & 0.9999 \\
\hline PCB180 & -1.17 & 453.16 & 161 & 0.9998 & 0.9999 \\
\hline
\end{tabular}

The linearity is the ability within a definite range to obtain results directly proportional to the concentration of the analyte. The concentrations of the validation standards were back calculated from the calibration curve. A linear regression model was fitted on the back-calculated concentrations as a function of the introduced concentrations. The intercept, the slope and the coefficient of determination of the equations obtained are presented in table (4). The slopes values close to 1 demonstrate the linearity of the method. The linearity was demonstrated for all PCBs in the range (0.01 to $0.2 \mathrm{ppm})$ because the coefficient determination are more than $0.995\left(\mathrm{r}^{2}\right)$.

Table 5:- Suitability test to the calibration model.

\begin{tabular}{|c|c|c|c|c|}
\hline PCB & Interpretation & Observed value & Critical Value * $\alpha=1 \%$ & Conclusion \\
\hline PCB28 & \multirow{7}{*}{$\begin{array}{c}\text { Field } \\
\text { calibration }\end{array}$} & 2.53 & \multirow{7}{*}{4.10} & \multirow{7}{*}{$\begin{array}{c}\text { The calibration domain is } \\
\text { validated }\end{array}$} \\
\hline PCB53 & & 2.45 & & \\
\hline PCB101 & & 1.90 & & \\
\hline PCB118 & & 3.89 & & \\
\hline PCB138 & & 1.11 & & \\
\hline PCB153 & & 3.27 & & \\
\hline PCB180 & & 3.45 & & \\
\hline
\end{tabular}

*: The critical value of Fisher with a $1 \%$ risk equals $\mathrm{F}(5,20,1 \%)$ corresponding to 4.10 (See fractile of Fisher law). «AFNOR 2009, NF T 90-210» 
The calibration function was verified by the Fisher test (Table 5). F ratio is less than the critical value of $\mathrm{F}$ corresponding to Fisher variable for a risk of $1 \%$. Then, the results show that the linear range is validated and the regression model is acceptable.

In conclusion, the calibration function is validated on the studied domain with a $1 \%$ risk because the error of the model is significantly negligible compared to the experimental error observed and the criterion observed is less than the critical value. Then the calibration function is linear over the analyzed range $[0,01 ; 0.2$ ppm]. (Figure 3 and 4 )

Figure 3:- Linearity graphs for a quadratic form
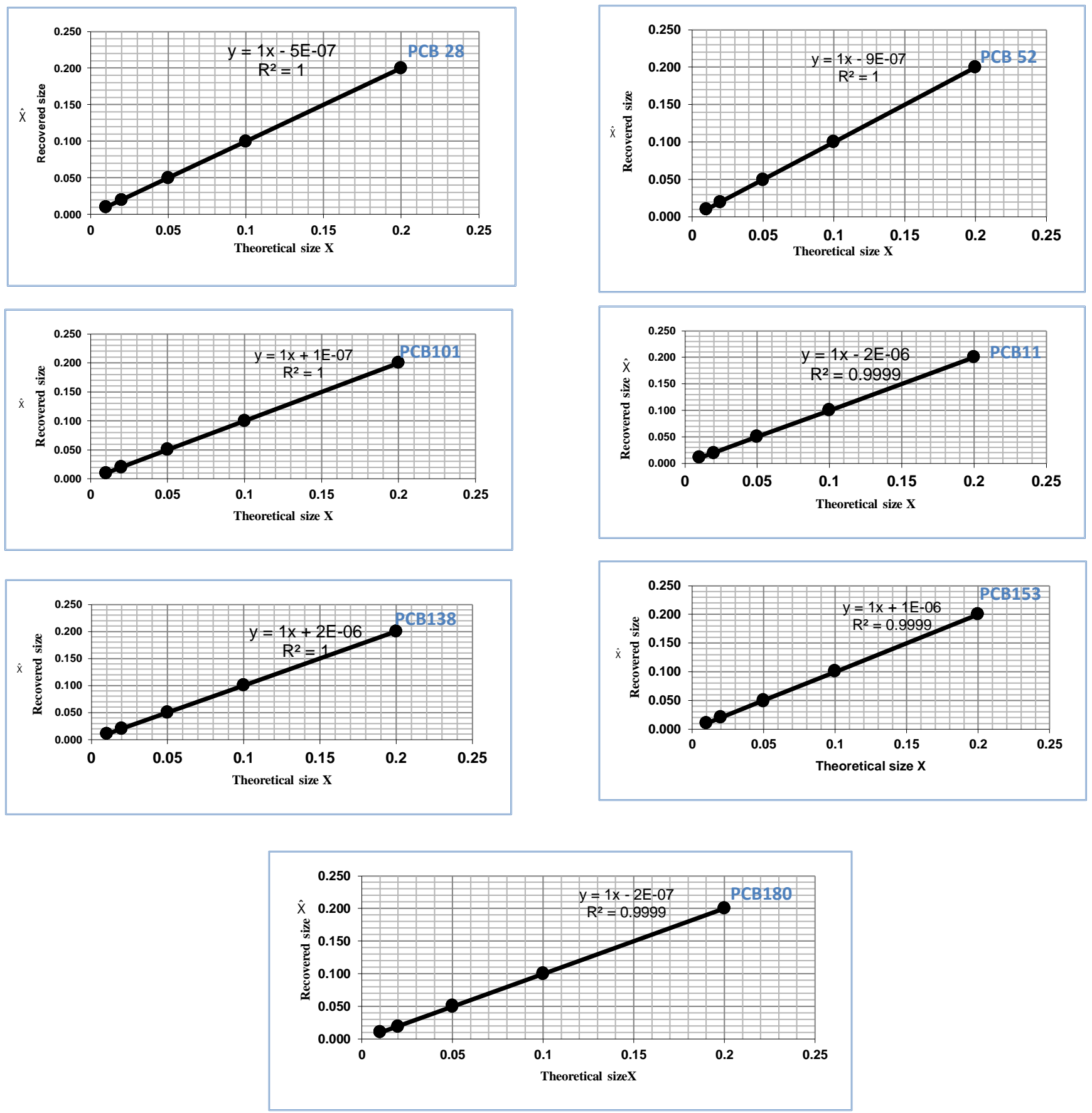
Figure 4:- Breakdown of bias in\% according to the levels compared to the calibration EMA defined by the laboratory.
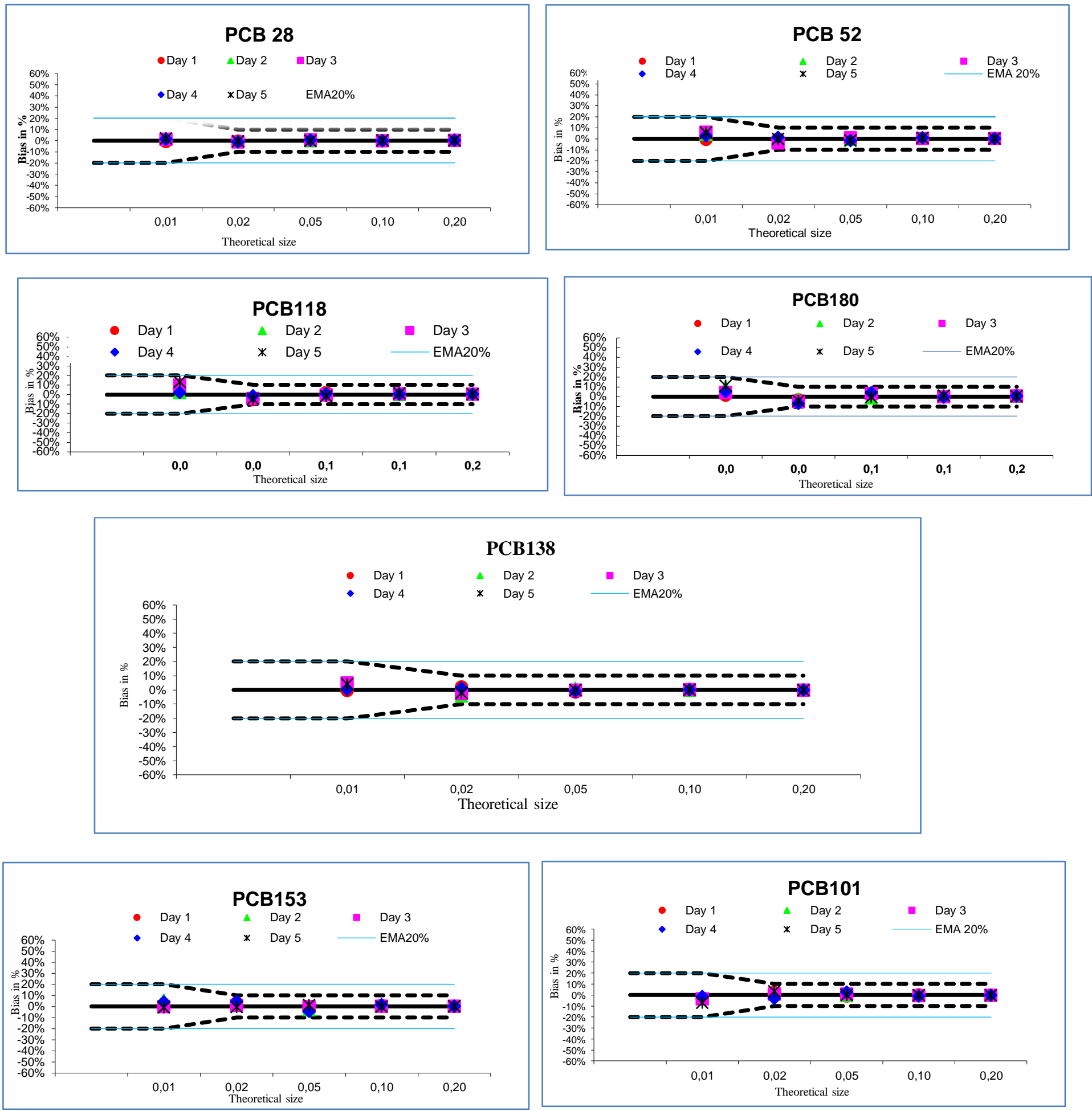
It is necessary to check that all the biases observed on each analyzed standard are acceptable from an acceptable maximum deviation fixed by the exporter.

All biases are lower than the fixed EMA for each standard then the calibration function is considered acceptable in the studied field.

In conclusion $\mathrm{R}^{2}>0.995$ for all molecules PCBs and $\mathrm{C}_{\text {model }}$ is less than $\mathrm{V}_{\text {critical model }}$ Thus the biases observed are lower than the EMA set by the experimenter.

The sensitivity of the used apparatus was estimated by determining limit of quantification (LOQ $=0.01 \mathrm{ppm})(\mathrm{Table}$ 6). These low LOQ indicate good sensitivity.

Table 6:- Results of limite of quantification (LQ=0.01ppm)

\begin{tabular}{|l|c|c|c|c|}
\hline PCBs & $\mathrm{LQ}+60 \% * \mathrm{LQ}$ & $\overline{\bar{z}} \mathrm{LQ}+2 \mathrm{~S}_{\mathrm{LQ}}$ & $\overline{\overline{\mathrm{z}}} \mathrm{LQ}-2 \mathrm{~S}_{\mathrm{LQ}}$ & $\mathrm{LQ}-60 \% * \mathrm{LQ}$ \\
\hline PCB28 & 0.016 & 0.012572815 & 0.007987185 & 0.004 \\
\hline PCB52 & 0.016 & 0.011628757 & 0.008491243 & 0.004 \\
\hline PCB101 & 0.016 & 0.011167194 & 0.008532806 & 0.004 \\
\hline PCB118 & 0.016 & 0.012348205 & 0.007111795 & 0.004 \\
\hline PCB138 & 0.016 & 0.011964594 & 0.006975406 & 0.004 \\
\hline PCB153 & 0.016 & 0.011649222 & 0.007150778 & 0.004 \\
\hline PCB180 & 0.016 & 0.011221538 & 0.007578462 & 0.004 \\
\hline
\end{tabular}

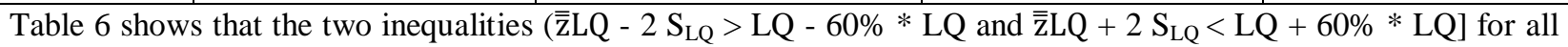
PCBs are verified.

Table 7:- Results of yields study [LQ, 20\% and 80\%]

\begin{tabular}{|l|c|c|c|c|}
\hline \multirow{2}{*}{ PCBs } & \multicolumn{3}{|c|}{ Average Yield \% } & \multirow{2}{*}{$\begin{array}{c}\text { Recovery rate } \\
\text { [sanco, 2015] }\end{array}$} \\
\cline { 2 - 4 } & $0.01 \mathrm{ppm}$ & $0.05 \mathrm{ppm}$ & $0.16 \mathrm{ppm}$ & 87.94 \\
PCB28 & 102.80 & 86.34 & 85.73 & \\
\hline PCB52 & 100.60 & 79.94 & 85.54 & [70\%;120\%] \\
\hline PCB101 & 98.50 & 80.42 & 86.09 & 87.49 \\
\hline PCB138 & 97.30 & 79.38 & 85.88 & \\
\hline PCB153 & 94.70 & 80.90 & 84.11 & \\
\hline
\end{tabular}

From the recovery study (Table 7), it is clear that the method is accurate for quantitative estimation of PCBs in bivalves as the statistical parameters are within the acceptance range (from $70 \%$ to $120 \%$ ) according to the most recent EU guidelines (SANCO, 2015).

For the study of accuracy an example of PCB 28 which is representative for all the other molecules will be shown. The same results were obtained for all PCBs.

The accuracy of the method is investigated on samples of reference value at $0.01 \mathrm{ppm}, 0.05 \mathrm{ppm}$ and $0.16 \mathrm{ppm}$. The used experimental values for the study of accuracy at these three levels of concentrations are derived from the LQ study and the study of yields.

The results are interpreted to verify the accuracy of the method against an acceptable deviation around each reference value set by the laboratory (Tables 8 and 9).

Table 8:- Estimation of the accuracy parameters of the method for three levels "PCB28"

\begin{tabular}{|l|c|c|c|}
\hline & Level 1 & Level 2 & Level 3 \\
\hline Reference value & 0,01 & 0,05 & 0,16 \\
\hline Uref & 0,2 & 0,2 & 0,2 \\
\hline EMA in \% & 64 & 50 & 45 \\
\hline EMA & 0,006400 & 0,0251 & 0,072 \\
\hline Number of series & 5 & 5 & 5 \\
\hline Average & 0,01028 & 0,04317 & 0,14071 \\
\hline Intermediate fidelity standard deviation & 0,001146 & 0,001663 & 0,012798 \\
\hline Intermediate fidelity CV & 11,2 & 3,9 & 9,1 \\
\hline
\end{tabular}


Table 9:- Interpretation of the accuracy parameters of the method for three levels and conclusions «PCB28»

\begin{tabular}{|l|c|c|c|}
\hline Standard deviation EN & 0,00140 & 0,03 & 0,10 \\
\hline Criterion & 2,00 & 2,00 & 2,00 \\
\hline Accuracy of the method & Verified & Verified & Verified \\
\hline Réf + EMA & 0,02 & 0,08 & 0,23 \\
\hline Z 2 SLQ & 0,01 & 0,05 & 0,17 \\
\hline Z - 2 SLQ & 0,01 & 0,04 & 0,12 \\
\hline Réf - EMA & 0,00360 & 0,02 & 0,09 \\
\hline Z + 2 SLQ <Réf + EMA & Verified & Verified & Verified \\
\hline Z - 2 SLQ >Réf - EMA & Verified & Verified & Verified \\
\hline Accuracy of the method & ACCEPTABLE & ACCEPTABLE & ACCEPTABLE \\
\hline
\end{tabular}

\section{Discussion:-}

Figure 2 showing the representative chromatogram for standard of polychlorinated biphenyls mixture. Adequate separation of the 7 PCBs was achieved. No interference peaks were obtained in the chromatogram at the same retention time of the target compounds. The linearity is the ability within a definite range to obtain results directly proportional to the concentration of the analyte. The concentrations of the validation standards were back calculated from the calibration curve. A linear regression model was fitted on the back-calculated concentrations as a function of the introduced concentrations. The intercept, the slope and the coefficient of determination of the equations obtained are presented in (Table 4). The slopes values close to 1 .Therefore, linearity has also been demonstrated for all PCBs in the range $(0.01$ to $0.2 \mathrm{ppm})$ because the coefficient determination are more than $0.995\left(\mathrm{r}^{2}\right)$. The calibration function was verified by the Fisher test (Table 5). F ratio is less than the critical value of $F$ corresponding to Fisher variable for a risk of $1 \%$. And also by a comparison of all observed biases on each standard analyzed are acceptable from an acceptable maximum deviation set by the exporter.

All biases are lower than the fixed EMA for each standard, the calibration function is considered acceptable in the field studied.Then, the results show that the linear range is validated and the regression model is acceptable. The sensitivity of the apparatus used was estimated by determining limit of quantification (LOQ=0.01ppm) $(\mathrm{Table} 6)$.

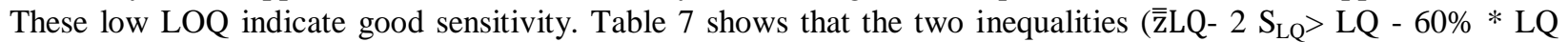
and $\left.\overline{\bar{z}} \mathrm{LQ}+2 \mathrm{~S}_{\mathrm{LQ}}<\mathrm{LQ}+60 \% * \mathrm{LQ}\right)$ are verified. Thus the accuracy of LOQ at $0.01 \mathrm{ppm}$ is verified. From the recovery study (Table 8), it is clear that the method is accurate for quantitative estimation of 7 PCBs in bivalves as the statistical parameters are within the acceptance range (from $70 \%$ to $120 \%$ ) according to the most recent EU guidelines (SANCO, 2015). The calculated accuracy error (Table 9) is less than 2. Then, it is considered insignificant [17]. Therefore, the uncertainty associated to accuracy of the method is equal to the uncertainty of the reference material used for testing accuracy study. Table 9 shows the value of Standard deviation EN $\leq \mathrm{Criterion}=2$ is verified. Therefore the method is just and shows that the two inequalities $(Z+2$ SLQ $<$ Réf + EMA and Z -2 SLQ $>$ Réf- EMA) are verified. Thus the accuracy at 0.05 and $0.16 \mathrm{ppm}$ are acceptable. The table below shows the example of PCB 28, which is a summary table of all the results of validation criteria of the same PCBs.

Table 10:- Summary table of all PCB validation criteria 28.

\begin{tabular}{|c|c|c|c|c|c|c|c|c|}
\hline \multicolumn{6}{|c|}{ Methode caractirisation } & \multirow{2}{*}{\multicolumn{2}{|c|}{ Observed value }} & \\
\hline \multirow{2}{*}{\multicolumn{3}{|c|}{ Calibration }} & \multicolumn{3}{|c|}{ Expected performance } & & & Conclusions \\
\hline & & & & & & & & LINEAR \\
\hline \multicolumn{9}{|c|}{ Fonction } \\
\hline \multicolumn{3}{|c|}{ Range of standard solutions } & 0,01 & 0,2 & $\mu \mathrm{g} / \mathrm{g}$ & \multirow[b]{2}{*}{ MAX = } & \multirow[b]{2}{*}{$2,0 \%$} & \\
\hline Bias in $\%$ For & 0,01 & $\mu \mathrm{g} / \mathrm{g}$ & \multicolumn{3}{|c|}{$20 \%$} & & & Verified \\
\hline Bias in \% For & 0,02 & $\mu \mathrm{g} / \mathrm{g}$ & \multirow{2}{*}{\multicolumn{3}{|c|}{$\frac{10 \%}{10 \%}$}} & MAX = & $-0,5 \%$ & Verified \\
\hline Bias in $\%$ For & 0,05 & $\mu \mathrm{g} / \mathrm{g}$ & & & & MAX = & $0,9 \%$ & Verified \\
\hline Bias in $\%$ For & 0,10 & $\mu \mathrm{g} / \mathrm{g}$ & \multicolumn{3}{|c|}{$\frac{10 \%}{10 \%}$} & MAX = & $0,1 \%$ & Verified \\
\hline Bias in \% For & 0,20 & $\mu \mathrm{g} / \mathrm{g}$ & \multicolumn{3}{|c|}{$10 \%$} & MAX = & $0,0 \%$ & Verified \\
\hline \multicolumn{3}{|c|}{ Fisher Test } & \multicolumn{3}{|c|}{4,10} & \multicolumn{2}{|c|}{2,53} & ACCEPTABLE \\
\hline \multicolumn{3}{|c|}{ Limit of quantification presupposed } & \multicolumn{2}{|r|}{0,01} & $\mu \mathrm{g} / \mathrm{g}$ & & ACCEPTABLE \\
\hline \multirow{2}{*}{\multicolumn{3}{|c|}{$\frac{\text { Acceptable maximum deviation }}{\mathrm{LQ}+40 \% * \mathrm{LQ}}$}} & & 0,006 & $\mu \mathrm{g} / \mathrm{g}$ & & & \\
\hline & & & & 0,016 & $\mu \mathrm{g} /$ & 0,01 & $\mu \mathrm{g}$ & Verified \\
\hline
\end{tabular}




\begin{tabular}{|c|c|c|c|c|c|c|}
\hline LQ $-40 \% *$ LQ & 0,004 & $\mu \mathrm{g} / \mathrm{g}$ & 0,01 & $\mu \mathrm{g} / \mathrm{g}$ & & Verified \\
\hline Recovery & & & & & & ACCEPTABLE \\
\hline Fortified sample 1 & 0 & $\mu \mathrm{g} / \mathrm{g}$ & & & & \\
\hline Add 1 & 0,05 & $\mu \mathrm{g} / \mathrm{g}$ & & & & \\
\hline Fortified sample 2 & 0 & $\mu \mathrm{g} / \mathrm{g}$ & & & & \\
\hline Add 2 & 0,16 & $\mu \mathrm{g} / \mathrm{g}$ & & & & \\
\hline Recovery sample 1 & \multicolumn{2}{|c|}{$70 \% ; 120 \%$} & \multicolumn{2}{|c|}{86,340} & $\%$ & Verified \\
\hline Recovery sample 2 & \multicolumn{2}{|c|}{$70 \% ; 120 \%$} & \multicolumn{2}{|c|}{87,944} & $\%$ & Verified \\
\hline Sample 1 Accuracy & & & & & & ACCEPTABLE \\
\hline Reference value & 0,01 & $\mu \mathrm{g} / \mathrm{g}$ & & & & \\
\hline Uref & 0,2 & $\mu \mathrm{g} / \mathrm{g}$ & & & & \\
\hline EMA & 0,01 & $\mu \mathrm{g} / \mathrm{g}$ & & & & \\
\hline EN & 2,0 & & \multicolumn{2}{|c|}{0,00} & & Verified \\
\hline$Z+2$ SLQ $<$ Réf + EMA & 0,0164 & $\mu \mathrm{g} / \mathrm{g}$ & \multicolumn{2}{|c|}{0,01} & $\mu \mathrm{g} / \mathrm{g}$ & Verified \\
\hline Z - 2 SLQ > Réf - EMA & 0,0036 & $\mu \mathrm{g} / \mathrm{g}$ & \multicolumn{2}{|c|}{0,01} & $\mu \mathrm{g} / \mathrm{g}$ & Verified \\
\hline Sample 2 Accuracy & & & & & & ACCEPTABLE \\
\hline Reference value & 0,05 & $\mu \mathrm{g} / \mathrm{g}$ & & & & \\
\hline Uref & 0,2 & $\mu \mathrm{g} / \mathrm{g}$ & & & & \\
\hline EMA & 0,03 & $\mu \mathrm{g} / \mathrm{g}$ & & & & \\
\hline EN & 2,0 & & \multicolumn{2}{|c|}{0,03} & & Verified \\
\hline Z + 2 SLQ < Réf + EMA & 0,07512 & $\mu \mathrm{g} / \mathrm{g}$ & \multicolumn{2}{|c|}{0,05} & $\mu \mathrm{g} / \mathrm{g}$ & Verified \\
\hline Z - 2 SLQ > Réf - EMA & 0,02488 & $\mu \mathrm{g} / \mathrm{g}$ & \multicolumn{2}{|c|}{0,04} & $\mu \mathrm{g} / \mathrm{g}$ & Verified \\
\hline Sample 3 Accurancy & & & & & & ACCEPTABLE \\
\hline Reference value & 0,16 & $\mu \mathrm{g} / \mathrm{g}$ & & & & \\
\hline Uref & 0,2 & $\mu \mathrm{g} / \mathrm{g}$ & & & & \\
\hline EMA & 0,07 & $\mu \mathrm{g} / \mathrm{g}$ & & & & \\
\hline EN & 2,00 & & 0,1 & & & Verified \\
\hline $\mathrm{Z}+2 \mathrm{SLQ}<\mathrm{Ref}+\mathrm{EMA}$ & 0,23 & $\mu \mathrm{g} / \mathrm{g}$ & $0,1^{\prime}$ & & $\mu \mathrm{g} / \mathrm{g}$ & Verified \\
\hline Z - 2 SLQ > Ref - EMA & 0,09 & $\mu \mathrm{g} / \mathrm{g}$ & 0,1 & & $\mu \mathrm{g} / \mathrm{g}$ & Verified \\
\hline
\end{tabular}

\section{Conclusion:-}

In this work, a recently developed method QuECHERS based on accuracy was applied to demonstrate the ability of the GC/MS-MS method to quantify the organochlorine pesticides concentrations in the range of $0.01 \mathrm{ppm}$ to $0.2 \mathrm{ppm}$. Figures of merit (Linearity, LOQ, Repeatability intermediate, Precision, Reproducibility and trueness) of the proposed GC/MS-MS procedure were satisfactory for the determination of polychlorinated biphenyls in bivalves "Oyters".

The data processing provided precise results and was corroded effectively for the validation of polychlorinated biphenyls. The procedure was successfully applied to the reel bivalve sample.

In conclusion, the QuEChERS method remains a method: fast, easy to implement, inexpensive, specific, exact, sensitive, multi-residual, repeatable and reproducible. According to the results of validation obtained the method proves effective for the detection and the dosage of the 7 polychlorinated biphenyls studied in the oysters of Walidia in "MOROCCO".

The QuEChERS method (Quick, Easy, Cheap, Effective, Rugged and Safe) has been readily accepted by many pesticide residue analysts and many quality control laboratories of marine products in particular and also that are intended for export.

This analytical method should be extended and used for the validation of other bivalves and other organic pollutants. 


\section{References:-}

1. F.HABTI and All validation of an analysis method of 13 organochlorine pesticide residues in bivalves "oyters" using quechers extraction and gaz chromatography-tandem mass spectrometry " $\mathrm{gc}-\mathrm{ms} / \mathrm{ms}$ `International Journal of Development Research Vol. 07, Issue, 03, pp.xxx-xxx, March, 2017, ISSN: 2230-9926

2. QuEChER, S. 2014. Method for the determination of pesticide residues in food commodities- a review, International Journal of Farm Sciences 4(4) : 161-165

3. European commission, Guidance document on analytical quality control and method validation procedures for pesticides residus analysis in food and feed, SANTE/11945/2015

4. Guidance document on analytical quality control and method validation procedures for pesticides residues analysis in food and feed., Safety of the Food Chain Pesticides and biocides, SANTE/11945/2015

5. Dossier PCB. Consulté sur le site de l'AFSSA. Disponible sous <http://1. www.afssa.fr/> (consulté en déc. 2008).

6. Meunier P. Rapport d'information sur le Rhône et les PCB : une pollution 2. au long cours. Assemblée nationale, 25 juin $2008, n^{\circ} 998,135$ p. 12

7. Organisation mondiale de la santé. Bureau régional pour l'Europe. 3. Substances chimiques dangereuses : les principaux risques pour les enfants. Copenhague, Rome, La Valette, aide-mémoire EURO/02/04, 25 mars 2004, $5 \mathrm{p}$.

8. Centre interprofessionnel technique d'études de la pollution 4. atmosphérique (Citepa). Émissions dans l'air en France, régions de la métropole. Répartition sectorielle et régionale des émissions de certaines substances en 2000. 2000 (mise à jour fév. 2005), 29p. Disponible sur <http://www.citepa.org/> (consulté en déc. 2008).

9. AFSSA 28/04/05. Avis du 22 mars 2005 relatif à l'établissement d'une 5. valeur maximale admissible de dioxines dans les eaux destinées à la consommation humaine. Disponible sous <http://www.afssa.fr/> (consulté en déc. 2008).

10. Institut de veille sanitaire. Étude nationale Afssa-InVS d'imprégnation 6. aux polychlorobiphényles (PCB) des consommateurs réguliers de poissons d'eau douce. Disponible sous <http://www.invs.sante.fr/ surveillance/pcb/impregnation_pcb.html> (consulté en déc. 2008).

11. Ministère de l'écologie, du développement et de l'aménagement 7. durables. Ministère de l'agriculture et de la pêche. Ministère de la santé, de la jeunesse et des sports. Plan national d'actions sur les PCB. Comité national de pilotage et de suivi du mercredi 6 février 2008, 11p.

12. Michel MARCHAND and all,Rapports scientifiques et techniques de l'ifremer, les polychlorobiphényles (pcb) en milieu marin biogéochimie et écotoxicologie, Institut/rançais de recherche pour l'exploitation de la mer,2016.

13. [ANASTASSIADES, $M$. and al. Fast and easy Multiresidue method employing acetonitrile extraction/partitioning and "dispersive solid-phase extraction" for the determination of pesticide residues in produce. Journal of AOAC International, v.86, p.412-431, 2003. Disponível em: <http://www.ncbi.nlm.nih.gov/ pubmed/12723926>. Acesso em: 30 abr. 2013.

14. MARIN, S. and al. Congener profile, occurrence and estimated dietary of dioxins and dioxin-like PCBs in foods marketed in the Region of Valencia (Spain). Chemosphere, v.82, p.1253-1261, 2011. Disponível em: <http://www.sciencedirect.com/science/ article/pii/S0045653510014384>. Acesso em: 30 abr. 2013. doi: 10.1016/j.chemosphere.2010.12.033.

15. BLIGH, E.G.; DYER, W.J. A rapid method of total lipid extraction and purification. Canadian Journal of Biochemistry and Physiology, v.37, p.911-917, 1959.

16. Brazil, v.45, n.8, p.1522-1527, ago, 2015.

17. Catarina Cruzeiro and All, Development and application of a QuEChERS-based extraction method for the analysis of 55 pesticides in the bivalve Scrobicularia plana by GC-MS/MS, Analytical and Bioanalytical Chemistry May 2016, Volume 408,pp 3681-3698.

18. Marie-Dominique Blanchin, Validation des méthodes d'analyse, Laboratoire de Chimie Analytique 2010

19. NF EN 15662 methode polyvalente de determination des residus des pesticides par GC-SM et SL/SM/SM avec extraction/partition avec des l'acetonitrile et nettoyage par SPE disperses - janvier 2009.

20. European commission, Guidance document on analytical quality control and method validation procedures for pesticides residus analysis in food and feed, SANTE/11945/2015.

21. NF T90-210,Protocole d`evaluation initiale des performances d`une methode dans un laboratoire,AFNOR 2009.

22. Laszlo Hollosi, Katerina Bousova, Michal Godula, Validation of the Method for Determination of Pesticide Residues by Gas Chromatography - Triple-Stage Quadrupole Mass Spectrometry, Thermo Fisher Scientific, Food Safety Response Center, Dreieich, Germany,2016. 